cally and diagnosed as a primary squamous-celled cancer. Treatment both with $\mathrm{X}$-Ray (2400 r), Redium and Radium Needles (during a week, total dose amounting to $21660 \mathrm{mg}$ hours) succeeded to make the growth to disaprear completely. Since then now about a year and a half, there is no sign of recurrence, neither any trace of lymph node metastase.

\title{
REPORT OF CASES OF PENDULOUS TONSILS
}

By

K. AKAIKE

(Department of Oto-Rhino-Laryngology, Tokyo Hospital of

Communication Minis'ry)

Among three cases of Pendulous Tonsils, seen during the past three years; one complained hoarse voise, snoring, and short breath when running. The third case had a feeling of something stuck in the throat. All these symptoms had developed after suffering from Angina. There were no abnormalities found in general body growth but there were signs of tuberçulous disposition in all three cases. The histologic findings and the mode of development led to the inference that a Hamartoma or a Hamartoblastoma had become productive as an effect of local inflammation.

\section{STUDIES ON THE MISHEARING OF SOUNDS}

By

S. HANDA.

(From the Otological Department, Medical School, Unizersity of Nagoya.)

The Power of hearing both of musical tones and of speech sounds was examined on 73 persons with impaired hearing by 'means of Hartman's tuning fork $\mathrm{C}, \mathrm{C}, \mathrm{C}_{2}, \mathrm{C}_{3}$ and $\mathrm{C}_{4}$ ) and the sounds of spoken syllables (ka, mo, re etc.).

During this experiment they were required to write down the syllables as they cought.

By this examination, (1) the relation between the power of hearing for musical tones and that for speech sounds and (2) the tendency of mishearing were found as follows:

I. In order to hear sounds clearly, such a bigh tone as $\mathrm{C}_{f}$ is far more 
necessary than lower tones such as $\mathrm{C}, \mathrm{C}: \mathrm{C}$.

II The consonants [s] and [w] are best audible; on the other hand, the consonants $[z],[d ;,[p]$, and [b] are difficult to be heard. The consonants [d], . [m], $[\mathrm{n}],[\mathrm{k}],[\mathrm{t}],[\mathrm{r}]$ and the vowels stand between the above two groups.

III. The mishearing often occurs in the following direction:

$[\mathrm{k}] \longrightarrow[\mathrm{hi}[\mathrm{r}] \longrightarrow[\mathrm{d}][\mathrm{g}] \longrightarrow[\mathrm{k}][\mathrm{p}] \longrightarrow[\mathrm{t}](\mathrm{n}] \longrightarrow[\mathrm{n}]$

IV. The mishearing proper to higher tone deafness is frequently found in the consonant (s). 